\title{
PUBLIC INVESTMENT IN INFRASTRUCTURE AND ECONOMIC GROWTH IN NIGERIA (1980-2020)
}

\section{Enya Fred Ota ${ }^{1}$ and Ezeali Benjamin O. $(\mathrm{PhD})^{2}$}

${ }^{1}$ Department of General Studies, Ihechukwu Madubuike Institute of Technology, P.M.B005, Nkwoagu-Amuda, Isuochi, Umunneochi L.G.A Abia State-Nigeria. Tel: +2348035731847

${ }^{2}$ Department of Public Administration, Ihechukwu Madubuike Institute of Technology, P.M.B005,Nkwoagu-Amuda, Isuochi, Umunneochi L.G.A Abia State-Nigeria

Cite this article:

Enya F.O., Ezeali B.O. (2021), Public Investment in Infrastructure and Economic Growth in Nigeria (19802020). African Journal of Economics and Sustainable Development 4(3), 1-22. DOI: 10.52589/AJESD0JM1VBER.

\section{Manuscript History}

Received: 15 July 2021

Accepted: 18 Aug 2021

Published: 5 Sept 2021

Copyright $\odot 2020$ The Author(s). This is an Open Access article distributed under the terms of Creative Commons AttributionNonCommercial-NoDerivatives 4.0 International (CC BY-NC-ND 4.0 ), which permits anyone to share, use, reproduce and redistribute in any medium, provided the original author and source are credited.
ABSTRACT: The paper examined Public Investment in Infrastructure and the Economic Growth of Nigeria. The study adopted Econometric analysis using E-View. The stationarity test carried out in the study showed that all the variables were all stationary at first difference,1(1) and because of this the researchers proceeded to determine evidence of co-integration among the variables, hence the result of the co-integration test shows that there is evidence of 2 co-integration equations which shows that there is a long run relationship among the variables. The ECM test was well signed having -0.019307 with a good Adjusted Coefficient of determination of $92.78 \%$ with a joint statistical probability of 0.00000 . The study had it that Public Investment in Technology, Educational infrastructure and Power all have positive relationship with the Economy whereas Transport has negative relationship with the Economy. The study went further to conclude that Public Investment plays important roles in stimulation the Nigerian Economy especially in this era of democracy.

KEYWORDS: Public Investment, Infrastructure, Economic Growth, Nigeria 


\section{INTRODUCTION}

\section{Background to the Study}

Infrastructure is a strategic economic growth driver. Its potentials are numerous, it serves as catalyst for public development in the government agenda such as health care delivery, transportation, education and food security.

Infrastructural level affects the developmental ratings of a nation. Infrastructure contributes to the score of Nigeria's economic growth.

Nwachukwu and Enoh (2011) explain that the investment attraction of building development by the public sector is strategic to all areas of the economy.

Government investment in infrastructure is enormous because it is capital-intensive and such expenditure grows the economy because it affects most human endeavors in various fields of life such as production, construction, technology, transport, power etc.

However, this public investment in infrastructure in Nigeria seems to be a waste of scare resources as the growth in economy does not physically depict infrastructural developments. Example our country has drastically failed in having constant power supply but this sector has been used to siphon millions of dollars by our government. This experience by the government spending much without significant result has also been the case with technology, education and other infrastructural development facilities that were not captured by this study.

However, there are divergent views by academic scholars as to whether or not public investment in infrastructure affects economic growth. Chan, Ramly and Abdkarim (2017).

Connolly and Li (2016) find that an increase in public investment has a significant adverse effect on economic growth. Also, Babalola (2015) finds that government investment has a significant positive impact on economic development in Nigeria.

Iheanacho (2016) investigated the contribution of government investment in infrastructure in Nigeria and found a negative and significant long-term relationship between economic growth and Mitchell (2005) argues that public investment in infrastructure by its nature is often economically destructive regardless of how it is financed.

\section{Statement of the Problem}

Nigeria as a country has been experiencing economic downturn due to dwindling oil revenue based on our mono-cultural type of economy the country runs. This means that the oil revenue determines what happens in the economy.

Nigeria as a country has suffered from corruption and the trend is still ongoing to the extent that transparency international's (2016) Corruption Perception Index (CPI) ranks Nigeria $136^{\text {th }}$ out of 176 countries surveyed.

Nigeria continues to increase investment in infrastructure with a view to grow the economy and ease the burden of the citizens with a view to having efficient transportation and 
communication, provision of basic health care delivery, food, security but ironically these investments do not deliver the desired goals.

As a result, the economic growth recorded by these investments has not translated into improved welfare as the case of developed economies in the world like USA.

The crux of this study is of the opinion that when government expends on education, road construction, healthcare delivery, transportation, power such an investment should be able to grow the economy. In order words there should be a casualty between government investment and economic growth and this cannot be if the government folds its arms and spends nothing.

Hence, it is essential to find out reasons why there is little or no growth in the economy irrespective of huge public investment in infrastructure especially in this era of democracy in Nigeria.

\section{Objectives of the Study}

The aim of this study is to investigate the public investment in infrastructure and economic growth in Nigeria.

- Specifically, the study will investigate how public investment in transport will affect economic growth in Nigeria.

- How public investment in educational infrastructure will affect economic growth.

- How Public investment in Power affects the Nigeria economy.

- How Public investment in Technology will affect Nigeria economy.

\section{Research Questions}

The following research questions will guide the study

- To what extent does public investment in Transport affect economic growth in Nigeria?

- To what extent will public investment in educational infrastructure affect Nigerian economic growth?

- To what extent will public investment in Power affect Nigerian economic growth?

- To what extent will public investment in Technology affect Nigerian economic growth?

\section{Research Hypothesis}

Ho1: Public investment in Transport does not have significant effect on economic growth in Nigeria.

Ho2: Public Investment in educational infrastructure does not have significant effect on economic growth in Nigeria. 
Ho3: Public investment in Power does not have significant effect on economic growth in Nigeria.

Ho4: Public Investment in Technology does not have significant effect on economic growth in Nigeria.

\section{Significance of the Study}

The study offers important insights for the government with regards to its investments in infrastructure. It targets public (government) actors working in the field of infrastructural developments of the sectors of the economy. Researchers, students and academics will find it highly useful as a reference.

The study will also be beneficial for the oversight functions of government in public finance administration. Those who carry out investment in infrastructures also will rely on research like this to gain insight into governance.

More so, donors and rating agencies may find this work useful for performance appraisal and financial analysis.

\section{Scope of the Study}

The study is based on public investment in infrastructure and economic growth in Nigeria between 1981-2020.

\section{Limitation of the Study}

Some of the constraints encountered in the process of this research work are time and finance and access to data.

\section{REVIEW OF RELATED LITERATURE}

The study is based on appropriate literatures and concepts looking for possible gaps in the existing body of research knowledge.

\section{Conceptual Literature Framework}

\section{Public Investment on Infrastructure}

It appears to have a consensus opinion that for a country to progress in its sustainable development goals, as advanced by the United Nations Development Programme (UNDP) 2015, there is need for strong growth in National income. Improvements in infrastructure quality and economic growth are also necessary because clearly, economic growth will affect citizens lives positively such as in the provision of social amenities and reduction of poverty.

Public investment tends to be measured quantitatively on an annual basis as a percentage of total nation income in a given period. 
It is divided between physical or tangible investment in infrastructure eg transport, telecommunications and buildings. Human or intangible investment in education skills and knowledge and investment in the consumption of goods and services eg welfare benefits and pensions.

Public investment generally constitutes a relatively small percentage of overall public spending that is frequently a major component of total national capital investment.

\section{Public Infrastructure in the World}

Infrastructure investments tend to be large-scale, expensive and long term in nature so that private sector cannot maintain them on its own, therefore government play a key role in planning, delivery, and financing infrastructural investments (Aghion etal, 2013).

In recent years, however both in Nigeria and other major economies, public-private partnership initiatives are built in order to maintain and finance such long projects as new needs and technologies emerge.

\section{Public Investments in Nigeria}

Public infrastructure investments have an important role in Nigeria aimed at reaching its development objectives. Nigeria in the past has adopted private sector-oriented development model when public investment in industrial sector diminished gradually and investments towards infrastructure came into prominence in government budget.

As the population increase constantly, it became imminent to increase large sale infrastructure investments in transportation, irrigation, energy, information and technology, health and education sectors.

Recently, Nigeria also sources alternative financing models on public investment on infrastructure in order to meet increasing financing needs in Nigeria because of her rapidly growing population (Sarah 2014).

\section{Economic Growth and Public Investment}

This is defined as the increase in the inflation-adjusted market value of the goods and services produced by the economy over a given period of time.

Since 1971, the growth performance of Nigeria has been relatively impressive. The annual growth rate of the economy was 3.5\% over the years. Between 1971-1981 period, the economy recorded a positive average growth rate of $3.0 \%$ while the ratio of public investment to GDP was $14 \%$ respectively.

After independence government made it a duty to direct public expenditures towards providing basic and necessary infrastructure.

At the same time, Nigerian economy was confronted with enormous development challenges necessitating a change in orientation. This made the government to introduce and implement national development plans in order to address and achieve the following: sustaining economic growth, creating employment, reducing income inequalities and eradicating poverty. 
Public investment in order to achieve the above objectives increased from $7.5 \%$ to $7.8 \%$ hence the average growth rate of the economy increased from $3.5 \%$ to $4.4 \%$.

The rate reassuring shows the continuing active participation of the public sector in the economy.

The study argues that when government investment is zero, there will be little economic growth because enforcing contracts, protecting life and property and infrastructural development would be complicated. Hence government investment is necessary.

\section{THEORETICAL LITERATURE REVIEW}

The study was based on the following theories;

\section{Stakeholder Theory}

Stakeholder theory is based on the assumptions that address morals and values detailed by freeman 1984. The theory recognizes that three are parties involved in management such as employees, customers, contractors, financiers, communities, public agencies, political groups, trade, associations, competitors and trade unions who sometimes scrutinize government spending. Stakeholder theory is used in this study as a critical diagnostic tool to identify the points at which stakeholders are vulnerable to breakdown in the spending process in the part of government spenders.

For instance, stakeholders, such as electorates, tax payers or simply citizens are interest in what the government offers from spending tax payers' money. They expect a business-like approach to governance in the areas of utmost good faith, transparency and accountability as ensured in new public management theory.

\section{New Public Management Theory}

Gruening 2001 in his theoretical basis of new public management explains that the N.P.M movement began in late the 1970s and early 1980s. Its first practitioners emerged in the United Kingdom under Prime Minister Margaret Thatcher and in the municipal governments in the United States that had suffered most heavily from an economic recession and tax revolts followed by New Zealand and Australia. The N.P.M theory involves the introduction of private sector management organization. Advocates of this theory argue for the incorporation of the basis of private sector methods and incentive structures to improve efficiency in government. Notwithstanding that government business is not for project, it should strive to deliver on its promises of the dividend of democracy. This is the only way its performance can be measured because there is no standard yardstick for measuring government performance. The measurement of the efficiency or effectiveness of government spending has been subjective to a large extent. Therefore, government should minimize time spent on analyzing uncertainty.

\section{Public Expenditure Theory}

The public sector has a role to play in the society to ensure smooth running of economic activities. Also, the goals of government are sometimes numerous and have several stakeholders involved. Therefore, to avoid chaos, efficiency and equity should guide public spending (Hindrizia \& Myles 2005). It explains that efficiency concerns the smooth running 
of public activities. Efficiency has to do with the coordination, collection and monitoring of government revenue and expenditure towards the provision of services to the stakeholders. Equity is about the fair sharing of public gains among stakeholders. The applicable public expenditure theory in this study is based on Wagner's law known as the law of increasing state funding.

Wagner's law states that for any country, public expenditure constantly rises as income growth expands. The law stipulates that in the process of economic development the share of the public sector in GDP has been increasing over time.

Studies have shown that if growth in expenditure matches economic growth, then it should also translate into economic development, however, this has not been the case in reality in developing nations like Nigeria because sometimes there are elements of fiscal illusion in government activities.

\section{Fiscal Illusion Theory}

The theory of Fiscal Illusion originates from the work of Puviani (1903) as cited in Mourao 2008.

Fiscal Illusion is about the misperception of fiscal parameters. It implies persistent views and biases about public budgetary decisions in any direction based on imperfect information (Afonso 2014).

Afonso argues that the benefits of government programmes appear to be remote and unrecognized by citizens while citizens feel more directly the impact of sources of financing the budget such as taxes. The estence of the theory is to expose the fact that sometimes the real programme of government is concealed to accommodate unnecessary spending. This theory is relevant to this study because the real benefits of infrastructure spending may not necessarily translate into economic growth in the same expectation because of the element of illusion in the system.

\section{Theory of Economic Growth}

As has been defined as an increase in the monetary value of goods and services of a country over a given period. It is measured by an increase in GDP adjusted for inflation and a nation is expected to continually improve its GDP for sustainability.

There are three types of economic growth theory: classical, neo-classical; and the solo-swan modern-day theories. This study attempts to investigate the solo-swan modern day theory which focuses on three factors that affect economic growth, including labour, capital and technology with particular focus on technology regarding with infrastructural advancement and economic growth as per GDP.

According to Qells 2015, the Solo-swan theory argues that it is technological advancement that grows an economy because labour and capital adjust according to the advancement recorded in technology. 


\section{Keynesian Theory}

The theory forming the basis of Keynesian economies were first presented by the British economist John Maynard Keynes. Keynes contrasted his approach with the aggregate supplyfocused classical economies that preceded his book. The interpretations of Keynes that followed are contentions. Keynesian theory presupposed that government intervention can stabilize an economy specially during a recession where there is little money to spend. The theory argues that with government technological intervention, there is increased spending and employment (Johan, Mahmud \& Papageorgiou, 2014).

Scholars argue that Keynesian theory sometimes fail because lower tax rates have been found to boost economic growth. Keynes also hold strongly that politicians and journalists often advocate the need to arise spending to enhance economic growth. However, in practical terms it is possible to spur economic advancement through tax concessions to attract investors and grow foreign direct investment as in the case of United Arab Emirates states like Dubai.

\section{EMPIRICAL LITERATURE REVIEW}

Empirical studies on the relationship between public and private investments and economic growth are quite extensive. Much of the research was stimulated by Eberts (1986), Aschauer (1989a, 1989b) and Munnell (1990) empirical studies on the relationship between government investments on economic infrastructure, and economic growth at national, regional and state levels.

These studies (Aschauer (1989a), Eberts (1986), and Munnell (1990)) all found a statistically significant positive relationship between public investment and economic growth. These studies sparked up remarkable interest. Subsequent empirical studies conducted in this area, either using a single-equation time series of the type adopted by Aschauer (1989a) or a cross-section analysis (Easterly and Rebelo 1993) mostly indicated a positive effect of public investment on growth.

The role of public capital spending, especially, public infrastructural investment has also been theoretically considered in a production function framework (Aschauer 1989a) and endogenous growth theory, Barro (1989 and 1990). Not surprisingly, these studies have been widely criticized both methodologically and, in the inference, drawn. Charles and Peterson (1984) for example, emphasized that the reported relationship may not mean causality. In addition, Aschauer (1989a) and Munnell (1990) findings were criticized by Tatom (1991) as being spurious as they did not account for stochastic trends in the data. In his analysis, he subjected the data to standard unit root tests and found them to be nonstationary. He then used the first differences of the variables to estimate the production function and concluded that the strong positive association between private output and public capital disappeared. MacMillan and Smyth (1994) estimated the VAR models using both levels and first differences of the variables; they also concluded and indicated negligible impacts of public capital on output.

Concurringly, Munnell (1992) maintained that using only the first differences of the variables may lead to misspecification bias since first differencing filters out the long run information in the data. He critically examined the literature and postulated that future research should give particular attention to the integration and co-integration properties of the variables. Raymond (1998) reexamined the issue using annual observations in United 
States data from 1948 to 1993. Employing both integration and co-integration tests, he concluded that public capital seemed positively related to output, labour and private capital in the long run. The results also suggested and inferred those innovations in public capital could have long-lasting effects.

Public capital responded positively to innovations in output, labour and private capital. Devarajan et al. (1996) raised the possibility that public expenditures such as capital investments that were generally viewed as productive might be unproductive. Distinguishing between productive and unproductive expenditures, they showed that the effects on growth of the shift in their respective shares in the expenditures depended not only on the productivity of the two expenditures but also on their initial shares. Thus, the increase in productive public expenditure might be unproductive if its initial share is already excessive. This implication was supported by data from 43 developing countries over 20 years. Namely, the relationship between capital expenditure and growth per capita was found to be negative while that between current expenditure and growth was positive. These results led them to conclude that governments of developing countries tended to "over-invest" in public capital.

Aschauer (1989a) fitted an aggregate growth regression for the United States using annual data for the period 1949 to 1985; concluded that public capital was significantly productive and noted that the productivity of public capital exceeded that of private capital during the period. At the same time, Aschauer (1989b) documented highly positive and significant contributions of public net investments to the growth rates using a pooled data set of the Group of Seven industrial countries over the period 1966-1985 Aschauer (1989b). Moreover, Munnell (1990) further substantiated the findings of high contributions of public capital. Employing cross-national data, Barro (1989, 1990), and Khan and Kumar (1997) also found some evidence for a positive relationship between public investments and output growth.

Other empirical studies found positive effects of public capital spending, particularly infrastructure! spending, on private investment, productivity and growth see, Pereira (2000, 200la and 200Ib); and Mittnik and Neumann (2001)]. These studies suggest that a decrease in public capital spending could be harmful for economic growth. Currently there are two related strands of research on the role of public capital spending in capital accumulation and economic growth. The first one focuses on the public investment spending and private investment nexus.

In this research area, many studies found significant complementarity's crowding-in effect, but some studies found inconclusive or contradictory results Argimon et al. (1997); Cardosa (1993); Aschauer (1989b), among others suggest that this ambiguity might be the result of using aggregate rather than disaggregate public investment, e.g. infrastructural public investment. Mustafa et al. (2002) found some evidence of crowding-out effect of total public investment on private investment; there was no significant effect of public infrastructural investment on private investment in the long-run. However, they found some evidence of complementarities between private and public investment over the short and medium-run. Their results suggest that the chronic macroeconomic instability seems to become a serious impediment to the public investment, and has shattered, or even reversed, the long-run complementarities.

Nazmi and Ramirez (1997) analyzed the impact on economic growth of public and private investment spending. They concluded that public investment expenditures had a positive and 
significant effect on output growth. At the same time public investment's impact on economic growth was statistically identical to the impact of private capital spending. The contribution of public investment to output expansion however came at the expense of private investment as indicating a significant crowding out effect. Using cross country data, Easterly and Rebelo (1993) find a positive effect of investment in transport and communication on economic growth. Canning et al. (1994) found positive effect of telephones on economic growth, while Sanchez (1998) also find a positive impact of road length and electricity generating capacity in explaining subsequent economic growth. In contrast, Tatom (1991, 1993a, 1993b) and Holtz-Eakin (1993 and 1994), and Holtz and Schwartz (1995) suggest that there is little evidence of an effect from infrastructure to income growth in a panel of U.S. state level data, particularly when fixed effects are included.

Fan et al. (2004) using regional-level data for 1977-1999, the study developed a conceptual framework and model to estimate effects of different types of government expenditure on agricultural growth and rural poverty in rural Thailand. The results show that most government investments such as agricultural Research and Development, irrigation, rural education, and infrastructure including roads and electricity, had positive impacts on agricultural productivity growth and rural poverty reduction. However, variations in their marginal effects on production and poverty reduction were large, among different types of spending and across regions.

\section{RESEARCH METHODOLOGY}

\section{Research Design}

Research design constitutes guidelines which direct the researcher towards solving the research problem. Ex post factor research is undertaken.

\section{Model Specification}

The model tries to examine public investment in infrastructure and the Nigerian economic growth between 1981-2018. The model specification adopted in this study borrowed from the work of Fan et al 2004 which as shown/

RGDP is the independent variables while PIED, PITR, PITCH, PIPOW are the dependent variables.

OLS Linear regression equation will give functional relationship of the above variable.

$\mathrm{Y}=\mathrm{a} 0+\mathrm{a}_{1} \mathrm{X}_{1}+\mathrm{a}_{2}+\mathrm{X}_{2}+\mathrm{a}_{3}+\mathrm{X}_{3}+\mathrm{a}_{4}+\mathrm{X}_{4}+\mu----(1)$

Hence RGDP $=\mathrm{a}_{0}+\mathrm{a}_{1} \mathrm{PIED}+\mathrm{a}_{2} \mathrm{PITR}+\mathrm{a}_{3} \mathrm{PITCH}+\mathrm{a}_{4} \mathrm{PIPOW}+\mu----(2)$

Where

$$
\begin{aligned}
& \text { RGDP = Real Gross Domestic Product } \\
& \text { PIED = Public Investment in Education }
\end{aligned}
$$




$$
\begin{aligned}
& \text { PITR = Public Investment in Transportation } \\
& \text { PITCH = Public Investment in Technology } \\
& \text { PIPOW = Public Investment in Power } \\
& \mu=\text { error term } \\
& a=\text { intercept }
\end{aligned}
$$

Putting them in the same base elements logging them

$\log \mathrm{RGDP}=\mathrm{a} 0+\mathrm{a}_{1} \log \mathrm{PIED}+\mathrm{a}_{2} \log \mathrm{PITR}+\mathrm{a}_{3} \log \mathrm{PITCH}+\mathrm{a}_{4} \log \mathrm{PIPOW}$

\section{Method of Data Analysis}

In order to determine the casual relationship among the variables, E-view econometrics techniques will be used to estimate the parameters.

\section{Test of Significance}

\section{T-Test}

The T-test is used to determine the statistical significance of the parameter estimates. A twotail test is used at 5\% level of significance. Decision: When the $t$-cal is greater than the $t-$ table, the parameter is statistically significant and vice versa.

\section{F-Test}

F-test is conducted for the overall significance of the model. Hence if F-cal is greater than Ftab at the $5 \%$ of level of significance, we conclude that our model is significant. However, if F-cal is less than F-tab, we conclude that our model is not significant and we reject our alternative hypothesis.

\section{Test of Goodness of Fit}

This test is carried out to find out the strength of the independent variables in explaining the charges in the dependent variables. The $\mathrm{R}^{2}$ is reported as the multiple coefficients of determination adjusted to take into account the degree of freedom associated with the sum of squares.

\section{Test for Stationarity}

Unit roots test will be conducted using Augmented Dickey-Fuller (ADF) and Philip-Perron (PP) tests.

\section{Test for Co-integration}

According to Cengiz and Dilip (2005), the relations among the variables play a significant and important role in economic analysis. In the short run the variables may drift apart. But in the long run they converge to equilibrium. The co-integration analysis provides an analytical instrument in this process. As defined by Engle and Granger (1987), the stationarity of a variable determines the degree of integration of the variable. 
African Journal of Economics and Sustainable Development

ISSN: 2689-5080

Volume 4, Issue 3, 2021 (pp. 1-22)

www.abjournals.org

Engle and Granger (1987), have demonstrated that the linear combination is integrated at any order less than $\mathrm{d}$, then these variables are integrated.

\section{Sources of data Collection}

Data used for the study will be secondary data and sourced from CBN statistical bulletin 1981 and 2020.

\section{DATA PRESENTATION, ANALYSIS AND DISCUSSION OF FINDINGS}

\section{Data Presentation}

Table 1: Data on Real Gross Domestic Product (RGDP), Public Investment on Technology (PITCH), Public Investment on Educational Infrastructure (PIED), Public Investment on Transport (PITR) and Investment on Power.

Table 1a

\begin{tabular}{|c|c|c|c|c|c|}
\hline Year & $\begin{array}{c}\text { Real GDP (N' } \\
\text { billion) }\end{array}$ & $\begin{array}{c}\text { Public } \\
\text { Investment in } \\
\text { Tech (N' } \\
\text { billion) }\end{array}$ & $\begin{array}{c}\text { Public } \\
\text { Investment in } \\
\text { Education (N' } \\
\text { billion) }\end{array}$ & $\begin{array}{c}\text { Public } \\
\text { Investment in } \\
\text { Transport (N' } \\
\text { billion) }\end{array}$ & $\begin{array}{c}\text { Public Investment } \\
\text { in power } \\
\text { (N' billion) }\end{array}$ \\
\hline 1981 & $15,258.00$ & 0.01 & 0.17 & 0.03 & 0.03 \\
\hline 1982 & $14,985.08$ & 0.01 & 0.19 & 0.04 & 0.04 \\
\hline 1983 & $13,849.73$ & 0.01 & 0.16 & 0.03 & 0.03 \\
\hline 1984 & $13,779.26$ & 0.01 & 0.20 & 0.04 & 0.04 \\
\hline 1985 & $14,953.91$ & 0.01 & 0.26 & 0.05 & 0.05 \\
\hline 1986 & $15,237.99$ & 0.01 & 0.26 & 0.05 & 0.05 \\
\hline 1987 & $15,263.93$ & 1.09 & 0.23 & 0.18 & 0.06 \\
\hline 1988 & $16,215.37$ & 0.10 & 1.46 & 0.23 & 0.22 \\
\hline 1989 & $17,294.68$ & 0.10 & 3.01 & 0.30 & 0.48 \\
\hline 1990 & $19,305.63$ & 0.10 & 2.40 & 0.29 & 0.43 \\
\hline 1991 & $19,199.06$ & 0.10 & 1.26 & 0.24 & 0.45 \\
\hline 1992 & $19,620.19$ & 1.49 & 0.29 & 0.55 & 0.93 \\
\hline 1993 & $19,927.99$ & 0.01 & 8.88 & 2.03 & 1.60 \\
\hline 1994 & $19,979.12$ & 0.26 & 7.38 & 0.45 & 1.14 \\
\hline 1995 & $20,353.20$ & 21.99 & 9.75 & 1.08 & 1.63 \\
\hline 1996 & $21,177.92$ & 0.24 & 11.50 & 2.07 & 0.16 \\
\hline 1997 & $21,789.10$ & 0.31 & 14.85 & 1.58 & 0.75 \\
\hline 1998 & $22,332.87$ & 0.24 & 13.59 & 1.92 & 1.13 \\
\hline 1999 & $22,449.41$ & 0.27 & 43.61 & 11.12 & 0.69 \\
\hline 2000 & $23,688.28$ & 0.27 & 57.96 & 3.03 & 14.23 \\
\hline 2001 & $25,267.54$ & 4.81 & 39.88 & 33.93 & 4.81 \\
\hline 2002 & $28,957.71$ & 4.26 & 80.53 & 29.39 & 6.12 \\
\hline 2003 & $31,709.45$ & 3.02 & 64.78 & 22.68 & 48.90 \\
\hline & & & & & \\
\hline
\end{tabular}


African Journal of Economics and Sustainable Development

ISSN: 2689-5080

Volume 4, Issue 3, 2021 (pp. 1-22)

www.abjournals.org

\begin{tabular}{|c|c|c|c|c|c|}
\hline 2004 & $35,020.55$ & 3.89 & 76.53 & 8.07 & 24.56 \\
\hline 2005 & $37,474.95$ & 4.74 & 82.80 & 8.04 & 22.03 \\
\hline 2006 & $39,995.50$ & 5.60 & 119.02 & 9.77 & 31.94 \\
\hline 2007 & $42,922.41$ & 6.46 & 150.78 & 32.16 & 43.06 \\
\hline 2008 & $46,012.52$ & 7.32 & 163.98 & 67.39 & 86.50 \\
\hline 2009 & $49,856.10$ & 24.54 & 137.12 & 90.03 & 230.52 \\
\hline 2010 & $54,612.26$ & 131.70 & 170.80 & 42.41 & 435.04 \\
\hline 2011 & $57,511.04$ & 37.40 & 335.80 & 13.10 & 60.30 \\
\hline 2012 & $59,929.89$ & 73.60 & 348.40 & 23.20 & 90.30 \\
\hline 2013 & $63,218.72$ & 53.16 & 390.42 & 18.51 & 141.10 \\
\hline 2014 & $67,152.79$ & 43.40 & 343.75 & 18.30 & 95.10 \\
\hline 2015 & $69,023.93$ & 29.99 & 325.19 & 24.39 & 95.10 \\
\hline 2016 & $67,931.24$ & 47.07 & 339.28 & 20.57 & 100.99 \\
\hline 2017 & $68,490.98$ & 69.13 & 403.96 & 29.97 & 128.47 \\
\hline 2018 & $69,810.02$ & 70.97 & 465.30 & 30.47 & 137.91 \\
\hline
\end{tabular}

Source: CBN Statistical Bulletin 2018 Edition

Table 1b

\begin{tabular}{|c|c|c|c|c|c|}
\hline Year & $\begin{array}{c}\text { Natural Log } \\
\text { of RGDP }\end{array}$ & $\begin{array}{c}\text { Natural Log } \\
\text { of PITECH }\end{array}$ & $\begin{array}{c}\text { Natural Log of } \\
\text { PIRDU }\end{array}$ & $\begin{array}{c}\text { Natural Log } \\
\text { of PITRAN }\end{array}$ & $\begin{array}{c}\text { Natural Log } \\
\text { of PIPOW }\end{array}$ \\
\hline 1981 & 30.36 & 15.98 & 18.92 & 17.29 & 17.33 \\
\hline 1982 & 30.34 & 16.11 & 19.05 & 17.42 & 17.46 \\
\hline 1983 & 30.26 & 15.96 & 18.90 & 17.27 & 17.31 \\
\hline 1984 & 30.25 & 16.17 & 19.11 & 17.48 & 17.51 \\
\hline 1985 & 30.34 & 16.43 & 19.37 & 17.74 & 17.78 \\
\hline 1986 & 30.35 & 16.44 & 19.39 & 17.76 & 17.79 \\
\hline 1987 & 30.36 & 20.81 & 19.23 & 19.01 & 17.89 \\
\hline 1988 & 30.42 & 18.38 & 21.10 & 19.24 & 19.20 \\
\hline 1989 & 30.48 & 18.42 & 21.83 & 19.50 & 19.99 \\
\hline 1990 & 30.59 & 18.45 & 21.60 & 19.48 & 19.89 \\
\hline 1991 & 30.59 & 18.44 & 20.95 & 19.29 & 19.92 \\
\hline 1992 & 30.61 & 21.12 & 19.49 & 20.13 & 20.65 \\
\hline 1993 & 30.62 & 16.47 & 22.91 & 21.43 & 21.19 \\
\hline 1994 & 30.63 & 19.37 & 22.72 & 19.91 & 20.85 \\
\hline 1995 & 30.64 & 23.81 & 23.00 & 20.80 & 21.21 \\
\hline 1996 & 30.68 & 19.28 & 23.17 & 21.45 & 18.89 \\
\hline 1997 & 30.71 & 19.54 & 23.42 & 21.18 & 20.44 \\
\hline 1998 & 30.74 & 19.31 & 23.33 & 21.38 & 20.84 \\
\hline 1999 & 30.74 & 19.41 & 24.50 & 23.13 & 20.35 \\
\hline 2000 & 30.80 & 19.42 & 24.78 & 21.83 & 23.38 \\
\hline 2001 & 30.86 & 22.29 & 24.41 & 24.25 & 22.29 \\
\hline & & & & & \\
\hline
\end{tabular}


African Journal of Economics and Sustainable Development

ISSN: $2689-5080$

Volume 4, Issue 3, 2021 (pp. 1-22)

www.abjournals.org

\begin{tabular}{|l|l|l|l|l|l|}
\hline 2002 & 31.00 & 22.17 & 25.11 & 24.10 & 22.53 \\
\hline 2003 & 31.09 & 21.83 & 24.89 & 23.84 & 24.61 \\
\hline 2004 & 31.19 & 22.08 & 25.06 & 22.81 & 23.92 \\
\hline 2005 & 31.25 & 22.28 & 25.14 & 22.81 & 23.82 \\
\hline 2006 & 31.32 & 22.45 & $Z 5.50$ & 23.00 & 24.19 \\
\hline 2007 & 31.39 & 22.59 & 25.74 & 24.19 & 24.49 \\
\hline 2008 & 31.46 & 22.71 & 25.82 & 24.93 & 25.18 \\
\hline 2009 & 31.54 & 23.92 & 25.54 & 25.22 & 25.16 \\
\hline 2010 & 31.63 & 25.60 & 25.86 & 24.47 & 26.80 \\
\hline 2011 & 31.68 & 24.34 & 25.54 & 23.30 & 24.82 \\
\hline 2012 & 31.72 & 25.02 & 25.58 & 23.87 & 25.23 \\
\hline 2013 & 31.78 & 24.70 & 26.69 & 23.64 & 25.67 \\
\hline 2014 & 31.84 & 24.49 & 25.55 & 23.53 & 15.23 \\
\hline 2015 & 31.87 & 24.12 & 26.51 & 23.92 & 15.28 \\
\hline 2016 & 31.85 & 24.57 & 25.55 & 23.75 & $1: 34$ \\
\hline 2017 & 31.86 & 24.96 & 26.72 & 24.12 & 25.58 \\
\hline 2018 & 31.88 & 24.99 & 26.87 & 24.14 & 25.65 \\
\hline
\end{tabular}

Source: Computed by the Researcher from the CBN Data

\section{Data Analysis}

The estimation procedure adopted for the study is the regression approach starting from unit root test for stationarity, Co-integration test for long run verification, Ordinary least square regression to check the goodness of fit of the model, Error correction model and Granger causality test using pair wire test.

\section{Unit Root}

The study conducted unit root test to test for stationarity of all the variables using Augmented Dickey Fuller (ADF) unit root test. The tests were conducted to avoid spurious regression. The result is presented in the table 2 below:

Table 2: ADF test

\begin{tabular}{|c|c|c|c|c|}
\hline Variables & At levels -T Stat & Prob Value & $\mathbf{5 \%}$ critical value & Remarks \\
\hline RGDP & 0.049319 & 0.9570 & -2.945842 & Not stationary \\
\hline PITEC & -1.146332 & 0.6861 & -2.948404 & Not stationary \\
\hline PIED & -2.118405 & 0.2391 & -2.954021 & Not stationary \\
\hline PITR & -1.514271 & 0.5154 & -2.943427 & Not stationary \\
\hline PIPOW & -1.053429 & 0.7232 & -2.945842 & Not stationary \\
\hline & At $1^{\text {st }}$ diff. & & & \\
\hline RGDP & -3.561925 & 0.0118 & -2.945842 & Stationary \\
\hline PITEC & -7.990475 & 0.0000 & -2.948404 & Stationary \\
\hline PIED & -7.673704 & 0.0000 & -2.945842 & Stationary \\
\hline PITR & -7.975163 & 0.0000 & -2.945842 & Stationary \\
\hline PIPOW & -8.389714 & 0.0000 & -2.945842 & Stationary \\
\hline
\end{tabular}


From the above, the null hypothesis of unit root is accepted if the calculated T-stat is much less than the critical value at 5\% level of significance. Since these variables are much less than their respective values as indicated in the table, the study accepted the null hypothesis and conclude that all the variables have unit root or non-stationary at level. However, all the variables were stationary at $1^{\text {st }}$ difference. This implies that all the variables were integrated to order 1(1). Having established that the variables were integrated of the same order at first difference, the study proceeds to determine the evidence of co-integration among the variables.

\section{Co-integration Test}

\begin{tabular}{|c|c|c|c|c|}
\hline \multicolumn{5}{|c|}{$\begin{array}{l}\text { Date: } 11 / 04 / 19 \text { Time: 08:45 } \\
\text { Sample (adjusted): } 19832018 \\
\text { Included observations: } 36 \text { after adjustments } \\
\text { Trend assumption: Linear deterministic trend } \\
\text { Series: LNRGDP LNPIITECH LNPIEDU LNPIT } \\
\text { Lags interval (in first differences): } 1 \text { to } 1 \\
\text { Unrestricted Cointegration Rank Test (Trace) }\end{array}$} \\
\hline $\begin{array}{l}\text { Hypothesized } \\
\text { No. of CE(s) }\end{array}$ & Eigenvalue & $\begin{array}{c}\text { Trace } \\
\text { Statistic }\end{array}$ & $\begin{array}{c}0.05 \\
\text { Critical Value }\end{array}$ & Prob. ** \\
\hline None * & 0.640191 & 91.09872 & 69.81889 & 0.0004 \\
\hline At most 1 * & 0.512910 & 54.30014 & 47.85613 & 0.0110 \\
\hline At most 2 & 0.413623 & 28.40510 & 29.79707 & 0.0717 \\
\hline At most 3 & 0.185844 & 9.188597 & 15.49471 & 0.3482 \\
\hline At most 4 & 0.048424 & 1.786877 & 3.841466 & 0.1813 \\
\hline \multirow{2}{*}{\multicolumn{5}{|c|}{ 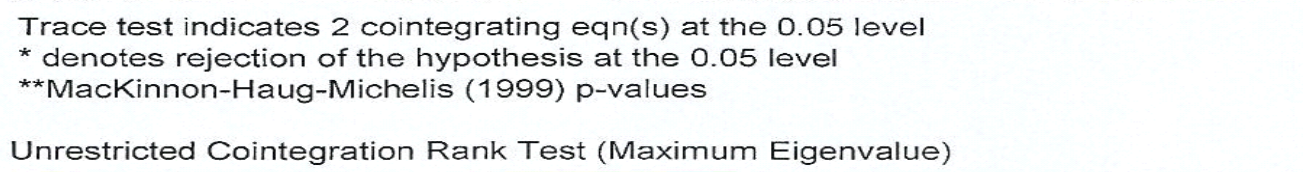 }} \\
\hline & & & & \\
\hline $\begin{array}{l}\text { Hypothesized } \\
\text { No. of CE(s) }\end{array}$ & Eigenvalue & $\begin{array}{c}\text { Max-Eigen } \\
\text { Statistic }\end{array}$ & $\begin{array}{c}0.05 \\
\text { Critical Value }\end{array}$ & Prob.** \\
\hline None * & 0.640191 & 36.79858 & 33.87687 & 0.0217 \\
\hline At most 1 & 0.512910 & 25.89504 & 27.58434 & 0.0809 \\
\hline At most 2 & 0.413623 & 19.21650 & 21.13162 & 0.0907 \\
\hline At most 3 & 0.185844 & 7.401720 & 14.26460 & 0.4428 \\
\hline At most 4 & 0.048424 & 1.786877 & 3.841466 & 0.1813 \\
\hline
\end{tabular}

Max-eigenvalue test indicates 1 cointegrating eqn(s) at the 0.05 level

* denotes rejection of the hypothesis at the 0.05 level

**MacKinnon-Haug-Michelis (1999) p-values

The result of the co-integration test is shown in table 2. From the table there is evidence of 2 co-integrating equations at $5 \%$ level of significance and this shows the variables have long run relationship among themselves. 
African Journal of Economics and Sustainable Development

ISSN: $2689-5080$

Volume 4, Issue 3, 2021 (pp. 1-22)

www.abjournals.org

\section{Ordinary Least Square Estimate}

\begin{tabular}{|c|c|c|c|c|}
\hline \multicolumn{5}{|c|}{$\begin{array}{l}\text { Ordinary least Square Regression } \\
\text { Dependent Variable: LNRGDP } \\
\text { Method: Least Squares } \\
\text { Date: } 11 / 04 / 19 \text { Time: } 08: 47 \\
\text { Sample: } 19812018 \\
\text { Included observations: } 38\end{array}$} \\
\hline Variable & Coefficient & Std. Error & t-Statistic & Prob. \\
\hline C & 27.09601 & 0.242425 & 111.7707 & 0.0000 \\
\hline LNPIITECH & 0.054843 & 0.020119 & 2.725924 & 0.0102 \\
\hline LNPIEDU & 0.097397 & 0.035403 & 2.751102 & 0.0096 \\
\hline LNPITRAN & -0.086832 & 0.035534 & -2.443625 & 0.0201 \\
\hline LNPIPOW & 0.106331 & 0.030873 & 3.444146 & 0.0016 \\
\hline R-squared & 0.926352 & Mean depend & t var & 30.99263 \\
\hline Adjusted R-squared & 0.917425 & S.D. depende & var & 0.561315 \\
\hline S.E. of regression & 0.161299 & Akaike info $\mathrm{cr}$ & rion & -0.689036 \\
\hline Sum squared resid & 0.858572 & Schwarz crite & & -0.473564 \\
\hline Log likelihood & 18.09168 & Hannan-Quin & criter. & -0.612373 \\
\hline F-statistic & 10.37689 & Durbin-Watso & stat & 1.032141 \\
\hline Prob(F-statistic) & 0.000000 & & & \\
\hline \multicolumn{5}{|l|}{$\begin{array}{l}\text { Estimation Command: } \\
================\end{array}$} \\
\hline \multicolumn{5}{|c|}{ LS LNRGDP C LNPIITECH LNPIEDU LNPITRAN LNPIPOW } \\
\hline \multicolumn{5}{|c|}{$\begin{array}{l}\text { Estimation Equation: } \\
==================\end{array}$} \\
\hline \multicolumn{5}{|c|}{ LNRGDP $=C(1)+C(2)^{*}$ LNPIITECH $+C(3)^{*}$ LNPIEDU + C $(4)^{*}$ LNPITRAN + C $(5)^{\star}$ LNPIPOW } \\
\hline \multicolumn{5}{|c|}{$\begin{array}{l}\text { Substituted Coefficients: } \\
=====================\end{array}$} \\
\hline \multicolumn{5}{|c|}{$\begin{array}{l}\text { LNRGDP }=27.0960088259+0.054843259381 * \text { LNPIITECH }+0.0973974141363^{*} \text { LNPIEDU }- \\
0.0868316523172^{*} \text { LNPITRAN }+0.10633051812^{*} \text { LNPIPOW }\end{array}$} \\
\hline
\end{tabular}

From the OLS result, it holds that the coefficient of determination $\mathrm{R}^{2}$ is $92.78 \%$ meaning that that $92.78 \%$ variation in the dependent variable is explained by the independent variable while the remaining $7.22 \%$ is explained by other variables not captured by the model which is represented by the error term $(\mu)$.

\section{Error Correction Model (ECM)}

The study employed Error Correction Model since all the variables were integrated at order 1(1). The Error Correction Model is shown in the table 4 below.

\section{Table 4}

\begin{tabular}{|l|l|l|l|l|}
\hline Predictor & Coefficient & Std Dev & T-stat & Prob Value \\
\hline C & 26.78304 & 0.280717 & 95.40930 & 0.0000 \\
\hline LNPTECH & 0.057691 & 0.020184 & 2.858221 & 0.0078 \\
\hline LNPTR & -0.068621 & 0.036966 & -1856337 & 0.0736 \\
\hline LNPOW & -099302 & 0.030693 & 3.235347 & 0.0030 \\
\hline ECM $(-1)$ & -0.019307 & 0.001593 & -12.119810 & 0.0459 \\
\hline
\end{tabular}


African Journal of Economics and Sustainable Development

ISSN: 2689-5080

Volume 4, Issue 3, 2021 (pp. 1-22)

www.abjournals.org

$\begin{array}{ll}\mathrm{R}^{2} & =0.927855 \\ \text { F-stat } & =74.59363 \\ \text { Prob (F-stat) } & =0.00000\end{array}$

\section{Granger Causality Test}

Through this test, the pair wise associations between the estimated variables are ascertained as presented in the table 5 below.

\begin{tabular}{|c|c|c|c|}
\hline Null Hypothesis: & Obs & F-Stalistic & Prob. \\
\hline $\begin{array}{l}\text { LNPIITECH does not Granger Cause LNRGDP } \\
\text { LNRGDP does not Granger Cause LNPIITECH }\end{array}$ & 36 & $\begin{array}{l}2.29913 \\
7.29691\end{array}$ & $\begin{array}{l}0.1172 \\
0.0025\end{array}$ \\
\hline $\begin{array}{l}\text { LNPIEDU does not Granger Cause LNRGDP } \\
\text { LNRGDP does not Granger Cause LNPIEDU }\end{array}$ & 36 & $\begin{array}{l}5.590866 \\
0.24498\end{array}$ & $\begin{array}{l}0.0111 \\
0.7842\end{array}$ \\
\hline $\begin{array}{l}\text { LNPITRAN does not Granger Cause LNRGDP } \\
\text { LNRGDP does not Granger Cause LNPITRAN }\end{array}$ & 36 & $\begin{array}{l}5.93669 \\
0.13057\end{array}$ & $\begin{array}{l}0.0066 \\
0.8781\end{array}$ \\
\hline $\begin{array}{l}\text { LNPIPOW does not Granger Cause LNRGDP } \\
\text { LNRGDP does not Granger Cause LNPIPOW }\end{array}$ & 36 & $\begin{array}{l}4.07566 \\
1.16738\end{array}$ & $\begin{array}{l}0.0105 \\
0.3245\end{array}$ \\
\hline $\begin{array}{l}\text { LNPIEDU does not Granger Cause LNPIITECH } \\
\text { LNPIITECH does not Granger Cause LNPIEDU }\end{array}$ & 36 & $\begin{array}{l}846574 \\
5.59681\end{array}$ & $\begin{array}{l}0.0012 \\
0.0084\end{array}$ \\
\hline $\begin{array}{l}\text { LNPITRAN does not Granger Cause LNPIITECH } \\
\text { LNPIITECH does not Granger Cause LNPITRAN }\end{array}$ & 36 & $\begin{array}{l}9.18660 \\
1.32592\end{array}$ & $\begin{array}{l}0.0007 \\
0.2802\end{array}$ \\
\hline $\begin{array}{l}\text { LNPIPOW does not Granger Cause LNPIITECH } \\
\text { LNPIITECH does not Granger Cause LNPIPOW }\end{array}$ & 36 & $\begin{array}{l}11.9451 \\
0.62848\end{array}$ & $\begin{array}{l}0.0001 \\
0.5401\end{array}$ \\
\hline $\begin{array}{l}\text { LNPITRAN does not Granger Cause LNPIEDU } \\
\text { LNPIEDU does not Granger Cause LNPITRAN }\end{array}$ & 36 & $\begin{array}{l}4.60635 \\
4.27093\end{array}$ & $\begin{array}{l}0.0177 \\
0.0230\end{array}$ \\
\hline $\begin{array}{l}\text { LNPIPOW does not Granger Cause LNPIEDU } \\
\text { LNPIEDU does not Granger Cause LNPIPOW }\end{array}$ & 36 & $\begin{array}{l}1.11475 \\
1.91216\end{array}$ & $\begin{array}{l}0.3408 \\
0.1648\end{array}$ \\
\hline $\begin{array}{l}\text { LNPIPOW does not Granger Cause LNPITRAN } \\
\text { LNPITRAN does not Granger Cause LNPIPOW }\end{array}$ & 36 & $\begin{array}{l}0.39801 \\
8.06675\end{array}$ & $\begin{array}{l}0.6750 \\
0.0015\end{array}$ \\
\hline
\end{tabular}

\section{DISCUSSION OF FINDINGS}

Based on the results of the estimation above, it was found that a stable long run relationship exists between the dependent variable and the explanatory variables in the model as supported by the presence of two co-integrating

equations. This means that the result of the finding of this study can be relied upon in taking long run policy decision regarding the Nigerian economy and public investments in infrastructure in the long run. 
This is in line work of Nazni and Ramirez (1997) who analyzed the impact on economic growth of public and private investment spending, they concluded that public investment expenditures have a positive and significant effect on output growth.

The long run equilibrium relationship is found from the normalized co-integrating coefficients as stated thus:

LNRGDP $=27.096+0.054$ LNPTCH + 0.097 LNPED - 0.086 LNTR + 0.106 LNPIPOW From the estimated model, 27.096 is the constant term, 0.054 is the coefficient of LNPTCH, 0.097 is the coefficient of LNPIED, -0.086 is the coefficient of LNTR and 0.106 is the coefficient of LNPIPOW.

From the result, it was observed that Public Investment in Technology, Educational Infrastructure and Power all have positive relationship (effect) in the economy whereas transport has a negative relationship.

It is imperative to say that more investments should be done in technology, education and power since they contribute positively to the growth of the economy while transport should be reformed to involve the government more.

The ECM actually met the apriori expectation of being negatively signed and it is fractional and statistically significant based on their p-values.

The R-square is $92.79 \%$ showing that $92.8 \%$ variation in the RGDP is explained by investments in technology, education, power and transport while the remaining $7.21 \%$ is explained by other variables not captured by the model which is represented by error term $(\mu)$.

The F-stat of 74.59 with p-value of 0.00000 which is less than 0.05 shows that the influence of technology, power, education and transport on the economy is statistically significant. This means that all the variables jointly and significantly impact on economic growth in Nigeria.

The pairwise granger causality test revealed unidirectional causality between LNRGDP and LNPITCH, LNRGDP and LNPIEDU, LNPITR and LNRGDP, LNPIPOW and LNRGDP, LNPITR and LNPTECH, LNPIPOW and LNPITCH, LNPITR and LNPIPOW whereas there is a bidirectional causality between LNPIEDU and LNPITCH and LNPITR and LNPIEDU while there was no causality between LNPIPOW and LNPIEDU.

\section{SUMMARY OF FINDINGS, CONCLUSION AND RECOMMENDATION}

\section{Summary of Findings}

The study investigated the public investment in infrastructure and economic growth in Nigeria from 1981-2018. The data used for the study was analyzed using E-view econometric technique. 
The findings reveal as follows:

- Public Investment in technology, educational infrastructure and power all have positive relationship with Real Gross Domestic Product in Nigeria under the period of study.

- Meanwhile public investment in transport has a negative relationship with the economic growth in Nigeria.

- However, the individual tests show that technology, educational infrastructure, and transport all have significant impacts on the RGDP at 5\% level of significant.

- The Joint test (F-stat) conducted at 5\% level of significance show that all the variables have significant impact on the RGDP.

- The test of goodness of fit of the model was conducted using the coefficient of determination. It was observed that $92.79 \%$ public investment in technology, education, transport and power all explains variations in RGDP while the remaining $7.21 \%$ was explained by factors not included in the model which was taken care of by the error term.

- The finding confirms that there exists a short run and long run relationship between public investment in infrastructure and economic growth. This implies that public investment impact positively on the economic growth in the short and long run processes.

- Other finding of the study confirms the existing empirical findings which are consistent by inferring a positive relationship between the selected infrastructure but the finding of this work is not in conformity given that transport has a negative relationship with economic growth. This could be as a result of the fact that Nigerian transport system is not yet reformed as is the case with other developed economies of the world.

\section{Conclusion}

Public investment in infrastructure on economic growth is a very interesting issue in Nigeria especially in this democratic era. The position of this study is that public investment plays important roles in stimulating Nigerian economic growth. However public investment plays a catalytic role in the economy.

It is through investment that production is expanded, human capital formation is enhanced and also digitalize the economy.

\section{Recommendations}

The study based on its findings recommend as follows:

- There is need to improve public investment in technology, and education in the best interest of the country especially this time the call for diversification of the economy is on the increase.

- A business-like approach to public investment in infrastructure which gives efficiency and equity should be incorporated within public governance.

- Nigeria should have a more detailed look at the transportation sector in order to have a more modernized transport system that can impact positively on the economy. 
- The financing options for closing Nigeria's infrastructure gaps should focus on broadening the sources of finance and a better allocation of public resources in those variables as outlined above.

- Government should also intensify the utilization of public-private partnership framework.

\section{REFERENCES}

Aghion P., Besley T., Browne J., Caselli F., Lambert R., Lomax R., Pissarides C., Stern C., Van Reenen J., 2013, "Investing for Prosperity", LSE Growth Commission.

Aschauer, D.A. and Lachler, U., 1998, "Public Investment and Economic Growth in Mexico", Policy Research Working Paper No. 1964, Washington, DC: The World Bank.

Aschauer, David A., 1989, "Is public expenditure productive?", Journal of Monetary Economics, Vol. 23, pp. 177-200.

Bayraktutan Y., 1992, "Kalkinma ve Altyapi", Ankara Universitesi Siyasal Bilgiler Fakultesi Dergisi, Vol. 47, No. 3, pp. 84-94.

Bom, P.R.D., J. E. Ligthart, 2014, "What Have We Learned from Three Decades of Research on the Productivity of Public Capital?", Working Paper, forthcoming Journal of Economic Surveys, Vo. 28, No.5, pp. 889-916.

Broyer, S., and J. Gareis, 2013, "How large is the infrastructure multiplier in the euro area?" Natixis FLASH Economics, No. 227.

Calderon C., Moral-Benito E., and Serven L., 2011, "Is Infrastructure Capital Productive? A Dynamic Heterogenous Approach", Policy Research Working Paper, No. 5682, The World Bank.

Canning, D. and E. Bennathan, 2000, "The social rate of return on infrastructure investments," World Bank Working Paper, WPS2390, World Bank, Washington DC.

Canning, D., M. Fay and R. Perotti. 1994, "Infrastructure and Growth" in Baldassarri, M., L. Paganetto and E. Phelps (eds), International Differences in Growth Rates: Market Globalization and Economic Areas, Central Issues in Contemporary Economic Theory and Policy Series, St. Martin's Press, New York.

Coe, D.T., E. Helpman, 1995, "International R\&D Spillovers", Economic European Review, Vol. 39, pp. 859-887.

Connolly, M., \& Li, C. (2016). Government spending and economic growth in the OECD countries. Journal of Economic Policy Reform, 19(4), 386-395.

Egert, B. T. Kozluk and D. Sutherland, 2009, "Infrastructure and growth: Empirical Evidence," OECD Economics Department Working Papers, No.685, OECD Publishing.

Embassy of the USA, 2012, "Better Infrastructure Brings Economic Growth", United States Department of State Bureau of International Information Programs.

Engsted, T., J. Gonzalo, N. Haldrup, 1997, "Testing for Multicointegration", Economics Letters, No. 56, pp. 259-266.

Eruygur A., M. Kaynak and M. Mert, 2012, "Transportation-Communication Capital and Economic Growth: A VECM Analyses for Turkey", European Planning Studies, Vol.20,No.2. pp. 341-363. 
European Commission, 2014, "Infrastructure in the EU: Developments and Impact on Growth", European Economy, Occasional Papers, No. 203.

Garcia-Mila, T., T.J. McGuire, and R. Porter, 1996, "The effect of public capital in statelevel production functions reconsidered", Review of Economics and Statistics, Vol.78, No. 1, pp. 177-180.

Hulten, C.R., 1996, "Infrastructure Capital and Economic Growth: How Well You Use It May Be More Important Than How Much You Have", NBER Working Paper No. 5847, Cambridge, MA: NBER.

Iheanacho, E. (2016). The contribution of Government Expenditure on Economic Growth of Nigeria Disaggregated Approach. International Journal of Economics \& Management Sciences, 5(5), 1-9. Doi:10.4172/2162-6359.1000369

IMF, October 2014, World Economic Outlook, Chapter 3.

Ismihan M., K. Metin-Ozcan and A. Tansel, 2005. "The role of macroeconomic instability in public and private capital accumulation and growth: the case of Turkey 1963 1999," Applied Economics, Taylor \& Francis Journals, Vol. 37(2), pages 239-251.

Loko B., M. A. Diouf, 2009, "Revisiting the Determinants of Productivity Growth: What's New?, IMF Working Paper, WP/09/225.

Marashoglu, H., A. Tiktik (1991), "Tiirkiye Ekonomisinde Sektorel Gelismeler : Uretim, Sermaye Birikimi ve tstihdam 1968-1988", DPT, Iktisadi Planlama Baskanhgi, DPT: 2271-IPB:428.

Meinen, G., P. Verbiest, P. De Wolf, 1998, "Perpetual Inventory Method: Service Lives, Discard Patterns and Depreciation Methods", Statistics Netherlands, Department of National Accounts.

Mitchell, D. J. (2005). The impact of government spending on economic growth. Heritage Foundation, 1831, 1-18.

Munnell, A.H., 1992, "Policy Watch: Infrastructure Investment and Economic Growth", Journal of Economic Perspectives, Vol. 6, pp. 189-98.

Nannan Y., M. Jianing, 2012, "Public Infrastructure Investment, Economic Growth and Policy Choice: Evidence from China", Crisis Management in the Time of Changing World.

Nwachukwu C. C., \& Emoh, F. (2011). Building construction project management success as a critical issue in real estate development and investment. American Journal of Social and Management Sciences, 2(1), 56-75. 10.5251/ajsms.2011.2.1.56.75.

OECD, 1999, ISDB 98, User's Guide, Paris. OECD, 2009, Measuring Capital, OECD Manual.

Pekbas, M. O., 2008, "Tiirkiye tcin Kamu Altyapi Yatirum Harcamalarmm Buyiime Uzerine Etkileri", Planlama Uzmanhgi Tezi, T. C. Kalkinma Bakanhgi, Ankara.

Pirili M.U., A. Lenger, 2012, "Bolgesel Kalkinmada Kamu Sermayesi ve Sosyal Altyapi: Turkiye Uzerine Bir Uygulama", Vol. 27, No. 312, pp. 9-37.

Roller, L-H. and L. Waverman, 2001, "Telecommunications infrastructure and economic development: A simultaneous approach", American Economic Review, Vol. 91, No. 4, pp. 909-23.

Saygili, S., C. Cihan, 2008, "Ttirkiye Ekonomisinin Buyiime Dinamikleri: 1987-2007 Doneminde Buyumenin Kaynaklan, Temel Sorunlar ve Potansiyel Buyiime Orani, TUSIAD ve TCMB, Yaym No. TUSIAD-T/2008-06/462. 
Saygili, S., C. Cihan, H. Yurtoglu, 2005, "Turkiye Ekonomisinde Sermaye Birikimi, Verimlilikve Btiyume (1972-2003): Uluslararasi Karsilastirma ve AB'ye Yakmsama Sureci (2014)", TUSIAD Arasstirma Raporlan Serisi, TUSIAD-T/2005-12/413.

Serdaroglu T., (2013), "Tiirkiye'de Finansal A9ikhk ve Toplam Faktor Verimliligi", Planlama Uzmanligi Tezi, Yaym No: 2853, T.C. Kalkmma Bakanhgl, Ankara.

Stock, J.H. (1987), "Asymptotic properties of least squares estimators of co-integrating vectors", Econometrica, No. 55, pp. 1035-1066.

T.C. Kalkmma Bakanhgl, 2012, "Dunya'da ve Tiirkiye'de Kamu-Ozel isbirligi Uygulamalarma lliskin Gelismeler", Yatinm Programlama Izleme ve Degerlendirme Genel Miidurlugii.

Tenth Development Plan (2014-2018), 2013, T.R. Ministry of Development, Ankara.

Uygur, E., (1990). "Policy, Productivity, Growth and Employment in Turkey, 1960-1989 and Prospects for the 1990s", Geneva: ILO, MIES Special Topic Study.

Wessels, W. J., 1997, "Microeconomics: The Easy Way" Barren's Educational Series, Inc. New York.

Yasar, P., (2008), "Alternatif Hasila Acigi Tahmin Yontemleri ve Phillips Egrisi: Turkiye Uzerine Bir Calisma, DPT Uzmanlik Tezleri, Ankara. 